\title{
A IMPORTÂNCIA DA LITERATURA PARA JURISTAS (SEM EXAGEROS)1
}

\author{
FÁbio Perin SheCAira ${ }^{2}$
}

\begin{abstract}
RESUMO: O principal objetivo deste artigo é discutir o valor moral da literatura para o jurista. A ideia comum (defendida por autoras como Robin West, Martha Nussbaum e Lynn Hunt) de que a literatura é capaz de "humanizar" o leitor - tornando-o mais compreensivo e benevolente - não tem sido claramente corroborada por estudos empíricos sobre o assunto. Além disso, trata-se uma ideia politicamente arriscada, que interessa tanto aos amigos quanto aos inimigos da literatura. Por outro lado, é possível argumentar que a literatura é capaz de sofisticar a nossa compreensão de problemas morais e sociais. Talvez a literatura não faça dos leitores pessoas melhores, mas ela ainda pode fazer dos leitores pessoas mais atentas à complexidade de questões morais que tendem a ser subestimadas.
\end{abstract}

Palavras-chave: direito na literatura; lições jurídicas; lições morais.

\section{INTRODUÇÃO}

É claro que juristas devem adquirir cultura geral e que a leitura frequente de bons romances, contos e poemas contribui para isso. Advogados que leem muito provavelmente serão capazes de escrever petições mais eloquentes e persuasivas. O mesmo princípio vale para as sentenças de juízes, para as denúncias de promotores e para os textos acadêmicos produzidos por professores de direito: quem lê mais costuma escrever melhor. Além de cultura geral e eloquência, no entanto, livros e

1 Agradeço a Marcelo de Araujo, Daniel de Souza Lucas e Noel Struchiner os comentários feitos em relação a uma versão preliminar deste artigo.

2 Doutor em Filosofia pela McMaster University (Canadá). Mestre em Filosofia pela Universidade Federal do Rio de Janeiro (UFRJ). Bacharel em Direito pela Universidade Federal do Rio de Janeiro (UFRJ). Professor Adjunto de Teoria do Direito da Universidade Federal do Rio de Janeiro (UFRJ). Rio de Janeiro (RJ), Brasil. CV Lattes: http://lattes.cnpq.br/9345542938572653. ORCID: https://orcid.org/o000-0002-43798708. E-mail: fabioperin@direito.ufrj.br. 
artigos sobre "direito e literatura" costumam destacar lições mais específicas que o jurista pode derivar de boas obras literárias: a saber, lições jurídicas e éticas. A natureza dessas lições será discutida a seguir.

O principal objetivo do artigo é explorar o valor moral da literatura para o jurista. A ideia comum de que a literatura é capaz de "humanizar" o leitor - tornando-o mais compreensivo e benevolente - está sujeita a diferentes objeções que serão discutidas na seção 3. Por outro lado, a literatura é capaz de sofisticar a nossa compreensão de problemas morais e sociais contemporâneos. Talvez a literatura não faça de nós pessoas melhores, mas ela incrementa a nossa capacidade de perceber a complexidade de questões morais que merecem reflexão cuidadosa. Essa sutil distinção - entre a humanização e a sofisticação do leitor - é um dos aspectos centrais do artigo.

A literatura não é a única fonte possível de lições sobre a complexidade de problemas morais contemporâneos. No ambiente universitário, essa função é tradicionalmente cumprida por livros de ética, filosofia política e outras obras semelhantes de "não-ficção". Sabemos, no entanto, que enquanto alguns leitores e estudantes preferem ouvir argumentos abstratos, outros são mais suscetíveis a narrativas. Do ponto de vista pedagógico, cursos que combinam os dois tipos de abordagem provavelmente terão mais chance de atrair a atenção dos dois tipos de estudantes - aqueles que gostam de analisar argumentos e aqueles que gostam de ouvir histórias.

A propósito, psicólogos fazem uma distinção entre a persuasão por meio de argumentos e a persuasão narrativa. São maneiras diferentes de tentar fazer com que um interlocutor passe a acreditar em alguma ideia (moral, política, social, científica etc.). Por exemplo, para tentar persuadir uma pessoa a repensar a forma como descarta seu lixo, é possível apresentar-lhe uma série de evidências sobre o impacto da produção doméstica de lixo no meio ambiente. Por outro lado, é possível contar uma história sobre indivíduos que, reciclando o seu lixo, foram capazes de afetar positivamente a comunidade em que vivem. Como explicam Philip Mazzocco e Melanie Green, o primeiro tipo de persuasão "apresenta uma série de argumentos lógicos e cogentes em defesa de um ponto de vista" 
(Mazzocco e Green, 2011, p. 27)3. A persuasão narrativa, por outro lado, "descreve uma série de eventos inter-relacionados que se dão em um ambiente particular e tipicamente envolvem personagens específicos. Sem usar argumentos explícitos, a persuasão narrativa é conduzida pelas ações e pela representação de antagonistas e protagonistas" (Mazzocco e Green, 2011, p. 27). Diante de um auditório plural, como costuma ser o auditório que ouve professores de direito, nada impede a combinação dos dois tipos de estratégia.

\section{LIÇÕES JURÍDICAS}

A ficção não costuma ser a melhor fonte de informação sobre o funcionamento interno de sistemas jurídicos específicos. Talvez haja algumas exceções, a exemplo de A balada de Adam Henry (2014), de Ian McEwan, que narra o dilema enfrentado por uma juíza inglesa encarregada de determinar se um jovem gravemente doente deve ou não ser obrigado a aceitar uma transfusão de sangue em detrimento de suas convicções religiosas. O livro apresenta a rotina de trabalho da juíza com tal riqueza de detalhes que o leitor atento pode aprender algumas coisas interessantes sobre o funcionamento do sistema jurídico inglês. Por exemplo, o livro ilustra bem a importância dos precedentes no raciocínio judicial e a natureza "adversarial" do processo legal inglês.

De maneira geral, no entanto, a leitura de romances não é a maneira mais fácil, nem a mais confiável, de aprender sobre as regras e procedimentos de sistemas jurídicos modernos. É comum que a literatura seja vista como fonte de lições mais gerais e abstratas a respeito do direito. São lições que ainda podem ser caracterizadas como "jurídicas" e que são importantes para a formação do jurista, mas que não dizem respeito aos detalhes burocráticos de qualquer sistema jurídico específico. Considere alguns exemplos de obras comumente exploradas em cursos de "direito e literatura". O mercador de Veneza (1596-1599) nos motiva a pensar sobre o formalismo excessivo que caracteriza muitos debates jurídicos e mostra que argumentos legalistas podem servir tanto para o bem quanto para o mal, tanto para beneficiar réu quanto para prejudicá-lo. O conto A Jury of Her

3 Esta e as demais citações de textos em inglês que aparecem ao longo do artigo são todas traduções minhas. 
Peers (1917), de Susan Glaspell, nos faz pensar sobre a dominação da mentalidade masculina, em detrimento da perspectiva feminina, no processo legal e sobre os erros de julgamento que decorrem desse desequilíbrio (sobretudo quando há mulheres entre os litigantes). O processo (1925), de Kafka, estimula reflexão sobre a frieza alienadora e a complexidade indecifrável da burocracia jurídica. O estrangeiro (1942), de Camus, destaca a obsessão do tribunal do júri pelo caráter do réu e por ações passadas que têm pouca relação com o crime julgado no momento. $O$ sol é para todos (1960), de Harper Lee, faz pensar sobre as obrigações éticas do advogado, sobretudo quando atua em um sistema jurídico opressivo e injusto.

Como se vê, as lições dessas obras clássicas transcendem fronteiras nacionais e especificidades jurídico-culturais: são lições que interessam a praticamente todo juiz e advogado, em praticamente qualquer sistema jurídico. Considere um último exemplo. Em As viagens de Gulliver (1735), o protagonista tenta explicar o funcionamento do direito inglês aos Houyhnhms, habitantes de uma sociedade idílica em que nunca existiram juízes e advogados (Swift, 1983, p. 229):

Importa observar também que essa sociedade [de
advogados e juízes] tem uma algaravia, ou geringonça
especial, que outros mortais não entendem, e na qual são
escritas todas as suas leis, que eles tomam o especial
cuidado de multiplicar, por onde conseguiram confundir
de todo ponto a própria essência da verdade e da
falsidade, da razão e da sem razão; por maneira que são
precisos trinta anos para decidir se o campo que me
legaram há seis gerações os meus antepassados pertence
a mim, ou pertence a um estranho que mora a 300 milhas
de distância.

É claro que essa é uma caricatura do direito, mas é uma caricatura instrutiva. É através da hipérbole, do exagero, que a sátira de Jonathan Swift dá visibilidade a alguns dos principais problemas que afetam a prática jurídica: o jargão incompreensível, o grande volume de leis obscuras, os julgamentos que contrariam o bom-senso de pessoas que não têm formação jurídica etc. Todo jurista deveria ser capaz de reconhecer esses problemas justamente para poder minimizá-los (digo “minimizá-los” porque sua plena eliminação é muito improvável). Todo jurista deveria parar em algum momento para pensar sobre como sua profissão é vista de fora, por pessoas que não conhecem o direito e talvez se sintam intimidadas ou alienadas por ele. 
As lições gerais que podem ser derivadas da literatura não estão, portanto, no nível da dita "dogmática jurídica" - isto é, dos temas explorados por disciplinas práticas como direito civil, penal, comercial, tributário etc. Elas estão no nível da teoria do direito, uma disciplina - ou melhor, um conjunto de disciplinas que abrange a filosofia do direito, a sociologia do direito, a história do direito etc. - que se dedica a discutir o direito em geral. A teoria do direito analisa o direito enquanto instituição social que costuma manifestar uma série de virtudes e deficiências e que se relaciona de maneira complexa com outros sistemas de regulação social: ética, política, religião etc. A literatura é uma fonte importante de estímulo para a reflexão sobre questões que estão no nível (filosófico, sociológico, histórico) da teoria do direito, não no nível da dogmática jurídica.

A teoria do direito é tradicionalmente ensinada através de livros de "não-ficção" escritos por especialistas em filosofia do direito, sociologia do direito, história do direito etc. $\mathrm{O}$ argumento proposto aqui não é o de que obras literárias seriam superiores aos livros especializados, nem o de que obras literárias deveriam substituir os livros especializados. Pelo contrário, do ponto de vista pedagógico, é interessante combinar os dois tipos de texto com o objetivo de expor estudantes a uma bibliografia variada e maximizar as chances de que todos tenham acesso ao tipo de texto que lhes parecerá mais persuasivo. A ideia, noutras palavras, não é substituir Hans Kelsen por Harper Lee, mas introduzir o estudante aos dois autores, no mesmo curso 4 .

\section{LIÇÕES ÉTICAS}

Também é comum que se diga que a literatura é uma fonte de lições éticas. Essa ideia está sujeita a duas interpretações, chamadas aqui de interpretação "forte" e interpretação "fraca". Nesta seção eu questiono a interpretação forte e defendo a interpretação fraca.

\subsection{Interpretação forte}

Segundo Robin West (1988, p. 877-878), "A literatura nos ajuda a entender os outros. A literatura nos ajuda a ter simpatia pela sua dor, a compartilhar seu sofrimento e a celebrar sua alegria. Ela nos torna pessoas

4 Para um relato detalhado de uma experiência pedagógica que combinou literatura e filosofia do direito, veja Philip Kissam (1998). 
mais éticas. Ela nos torna pessoas melhores”. West acredita que a literatura é capaz de humanizar o jurista. O advogado que entre em contato com a literatura será menos oportunista. O juiz, menos frio. $\mathrm{O}$ promotor, menos insensível ao sofrimento do réu. $\mathrm{E}$ assim por diante.

Outra autora que fez muito para dar credibilidade a essa ideia foi Martha Nussbaum. Nussbaum (1995, p. 27-34; 90-97) argumenta que o romance é particularmente eficaz na transformação moral do jurista. A própria estrutura do romance tende a comunicar uma mensagem igualitária. Embora lide com temas universais (amor, morte, traição, justiça etc.), o romance mergulha profundamente na vida de personagens específicos (Madame Bovary, Capitu, Pedro Bala, Macabéa). Para garantir efeito dramático, o romance costuma se concentrar na vida de personagens que sofrem de alguma forma (em virtude da pobreza, da traição, da discriminação etc.). Segundo Nussbaum, essa combinação de elementos universalidade do tema, foco em personagens específicos e sofrimento tem um efeito subversivo. É mais difícil preservar nossos estereótipos e preconceitos em relação a certos grupos sociais depois de entrar em contato com uma história verossímil sobre o sofrimento de indivíduos que integram aquele grupo.

Nussbaum dá como exemplo o romance Maurice (1971), de E. M. Forster. Maurice leva o leitor a acompanhar de perto o sofrimento de um homem homossexual na Inglaterra do início do século XX. O livro não apresenta argumentos abstratos contra a homofobia; ele nos convida a viver o drama de um indivíduo específico, que se sente atraído por outros homens e sofre intensamente por causa disso. As convenções sociais o rejeitam, a própria família não o entende, e ele se sente só. O mais importante, segundo Nussbaum, é que o livro evita o estereótipo do homossexual como homem de vida dissoluta. Maurice, o protagonista, é um homem de classe média que não tem nada de especial - não é bom nem mau, não é herói nem vilão. A única coisa que o distingue, a razão de seu sofrimento, é o fato de ser homossexual.

Outra autora cuja obra mostra-se relevante para essa discussão é Lynn Hunt (2009). Hunt faz uma afirmação sobre impacto moral da literatura que é ao mesmo tempo mais modesta e mais audaciosa do que as ideias de West e Nussbaum. Hunt acredita que o crescimento do romance 
epistolar como gênero literário no século XVIII contribuiu para o surgimento da noção de direitos humanos. O enredo de obras como Júlia (1761), de Rousseau, desenvolve-se por meio de cartas que revelam a intimidade dos personagens. Romances epistolares comoveram gerações de leitores que teriam sido estimuladas a expandir os limites da sua empatia, para além da comunidade imediata, em direção a outros grupos e culturas. A tese de Hunt é audaciosa porque trata o romance epistolar como um dos fatores responsáveis pelo estabelecimento de um dos conceitos políticos mais importantes da modernidade - o conceito de direitos humanos. Por outro lado, a tese de Hunt é relativamente modesta na medida em que diz respeito a um tipo específico de obra literária que fez sucesso em um momento histórico específico. Talvez Hunt não dissesse que a literatura torna as pessoas melhores (em diversos momentos e contextos), mas que certo tipo de literatura contribuiu para o progresso social em dado momento histórico. Se a literatura mantém esse poder, contemporaneamente, é outra questão. (As ideias de Hunt voltarão a ser discutidas na seção 3.3.)

\subsection{Esclarecimentos sobre a interpretação forte}

É possível comover-se com o sofrimento de outra pessoa (real ou fictícia) sem ser impelido a ajudá-la ou a ajudar outras pessoas em situação semelhante. Noutras palavras, a empatia e a simpatia não levam necessariamente a ações benevolentes ${ }^{5}$. West e Nussbaum parecem pensar que a literatura é capaz, não só de comover o leitor, de fazer com que ele seja afetado pelos sentimentos de personagens de ficção, mas também de levar o leitor a mudar em alguma medida seu comportamento diante de pessoas que enfrentem problemas análogos. Esse é um dos motivos pelos quais a posição dessas autoras pode ser dita "forte". Elas pensam que a literatura é capaz mudar a opinião e o comportamento do leitor, tornando-o

5 Empatia e simpatia são conceitos sutilmente diferentes (Keen, 2007). Temos empatia por outra pessoa quando sentimos o que ela sente (sofremos com seu sofrimento, alegramonos com sua alegria). Por outro lado, a simpatia não se dá quando sentimos o mesmo que outra pessoa, mas quando um sentimento de apoio é estimulado em nós por aquilo que outra pessoa sente (sentimos pena por causa do sofrimento de outra pessoa ou alívio diante de sua alegria). Empatia pode levar à simpatia e, assim, à ação benevolente. Mas isso nem sempre ocorre. A empatia também pode ter o efeito inverso, de gerar um sentimento de aversão que nos leva a evitar o assunto em vez combater o problema. Pense na pessoa que, diante do sofrimento de um personagem em um filme, prefere parar de assistir para não sofrer também. 
uma pessoa melhor. (Hunt talvez dissesse que a literatura foi capaz de mudar a mentalidade política do leitor do século XVIII, o que não é o mesmo que apostar na sua capacidade de continuar exercendo influência moral sobre o leitor contemporâneo.)

Outra distinção importante diz respeito ao impacto moral da leitura de obras literárias em contraste com o impacto moral do ensino da literatura no ambiente escolar ou universitário. Uma coisa é dizer que a leitura de romances tem efeito positivo no comportamento das pessoas; outra coisa é dizer que cursos de literatura (ou de "direito e literatura") têm efeito positivo no comportamento das pessoas. West e Nussbaum afirmam que a leitura de obras de ficção, por si só, tem um efeito positivo na formação do jurista. Para elas, é importante que juízes e advogados leiam romances como Maurice. Seria ainda melhor se eles tivessem a oportunidade de discutir o livro profundamente em sala de aula, sob a orientação de um especialista, mas nada disso parece ser estritamente necessário.

Em síntese, autoras como West e Nussbaum pensam que a leitura de obras literárias tem, por si só, um efeito positivo no comportamento de juristas. Esta é a ideia que eu pretendo questionar a seguir.

\subsection{Objeções à interpretação forte}

As ideias de West e Nussbaum são plausíveis e atraentes. No entanto, elas estão sujeitas a algumas objeções importantes. Nesta seção, eu formulo três objeções. A primeira objeção é bem conhecida entre estudiosos de "direito e literatura". As outras duas são menos conhecidas.

Primeira objeção: se há obras boas, também há obras más. Se a literatura é capaz de nos humanizar, então talvez ela também seja capaz de gerar o efeito contrário. Nem todo livro terá uma mensagem benevolente como a de Maurice. Alguns livros, apesar de muito bem escritos, podem ser imorais ou, no mínimo, moralmente controversos. Se a literatura é tão persuasiva, como pensam West e Nussbaum, então ela pode levar o leitor a adotar opiniões morais dos mais diversos tipos, para o bem e para o mal. Como diz Joshua Landy (2008, p. 79), “qualquer pessoa que possa ser convertida a um ponto de vista pela ficção pode ser convertida no sentido contrário pela própria ficção. Se Gandhi [o filme] basta para me transformar em pacifista na quinta-feira, então Malcolm $X$, que eu vejo na noite seguinte, é capaz de me fazer crer na necessidade da violência”. 
Segundo Richard Posner (2009, p. 462), os clássicos da literatura estão "repletos de atrocidade morais [...] representadas com aceitação acrítica e muitas vezes com gosto.” Posner formula uma longa lista de atrocidades que aparecem em obras literárias famosas - por exemplo: homicídio, escravidão, misoginia, racismo, homofobia, fascismo, obscurantismo religioso, tortura, mutilação e sadismo. O que revela essa lista de atrocidades? Em vez de dizer que "a literatura nos ajuda a entender os outros", o máximo que West poderia dizer é que uma parte - talvez a menor parte - da literatura nos ajuda a entender os outros, enquanto outra parte estimula preconceito, ódio, vingança, elitismo, machismo etc. A literatura nem sempre ataca estereótipos; às vezes ela incorpora e reafirma estereótipos que já estão em vigor.

Segunda objeção: a ideia de que a literatura é influente também é popular entre censores. Além de notar que nem toda obra literária carrega o tipo de mensagem valorizado por West e Nussbaum, é importante manter em mente os riscos políticos associados à disseminação da ideia de que obras literárias são persuasivas. A ideia de que a literatura tem influência sobre nossas crenças e comportamento é frequentemente usada por instituições oficiais interessadas em controlar a expressão artística. Tome o caso de Madame Bovary (1856), romance que enfrentou problemas jurídicos por explorar o tema do adultério, tabu na França do século XIX. Uma das preocupações do promotor do caso era justamente que Madame Bovary tivesse má influência sobre jovens leitoras: "Quem lê o romance do Sr. Flaubert? Serão homens que se ocupam de economia política ou social? Não! As páginas levianas de Madame Bovary caem em mãos mais levianas, nas mãos de moças, algumas vezes de mulheres casadas" 6 .

Em um relatório interno, um funcionário da censura russa afirmou que o livro de Ivan Turguêniev, Memórias de um caçador (1852), "faz mais mal do que bem”. A acusação é elaborada nos seguintes termos (Turguêniev, 2017, p. 478)7:

Que utilidade tem, por exemplo, mostrar ao nosso povo letrado [...] que nossos camponeses são oprimidos, que os

6 Este é um trecho do discurso de Ernest Pinard, transcrito como parte dos autos do processo movido contra Flaubert em uma das edições brasileiras de Madame Bovary (Flaubert, 2009, p. 317).

7 A citação aparece no posfácio de Irineu Franco Perpetuo. 
proprietários de terras, que o autor tanto achincalha, expondo-os como torpes, selvagens e extravagantes, comportam-se de forma indecente e ilegal, que o clero das aldeias rasteja diante dos proprietários de terras, que isprávniki e outras autoridades aceitam suborno e que, obviamente, quanto mais livres os camponeses forem, melhor? Não acho que tudo isso possa trazer algum proveito ou satisfação ao leitor virtuoso; pelo contrário, todos os relatos desse gênero deixam uma sensação desagradável.

Por mais antipática que nos pareça a opinião do censor no caso específico das Memórias de um caçador, essa opinião se apoia na ideia básica (compartilhada por West e Nussbaum) de que histórias bem contadas têm poder persuasivo. Elas teriam impacto sobre a nossa maneira de pensar e agir; elas seriam capazes de transformar nossas opiniões e nossos valores. É importante manter em mente, portanto, que a "faca" corta para os dois lados. A ideia de que a literatura ajuda a moldar o pensamento do leitor é tanto motivo de celebração entre os amigos da literatura como fonte histórica de motivação da censura. A lista de autores que foram alvo de censura ao longo da história é impressionante. Ela inclui Flaubert, Turguêniev, D.H. Lawrence, Joyce, Nabokov, Soljenitsin, Jorge Amado, Plinio Marcos etc. ${ }^{8}$

Terceira objeção: as evidências empíricas da influência da literatura não são fortes. A ideia de que a literatura é capaz de humanizar o jurista (assim como a ideia de que ela é capaz de fazer o contrário) repousa em suposições empíricas que merecem ser investigadas com cuidado. É verdade que um romance pode alterar significativamente nosso ponto de vista, descontruindo nossos estereótipos e preconceitos? Se um romance é capaz de nos mudar para melhor, ele também não poderia nos mudar para pior? Felizmente, há na literatura internacional alguns estudos empíricos sobre o assunto. Alguns são estudos psicológicos; outros são estudos são histórico-sociológicos.

Entre os estudos do primeiro tipo emerge uma noção particularmente importante, a noção de transporte (Liao e Gendler, 2010, p. 84-87). O transporte é o processo psicológico que se dá quando um leitor mergulha no mundo da ficção e perde momentaneamente contato com o mundo real.

8 Elisabeth Ladenson (2007) analisa em detalhe as controvérsias jurídicas que surgiram em torno de algumas dessas obras. 
Interessante é o que acontece quando o leitor "retorna" da viagem imaginativa (Mazzocco e Green, 2011, p. 27-28):

[...] os recebedores de uma narrativa persuasiva (filmes, livros, comunicações verbais etc.) podem ser mentalmente transportados para o mundo da história [...]. Enquanto estão dentro desse mundo-história, participantes perdem parcialmente o contato com o seu próprio mundo. Dessa forma, narrativas podem funcionar como uma forma de fuga da realidade. Quando retornam ao seu mundo, a teoria do transporte sugere que eles costumam retornar carregando as influências do mundo-história. [...] Por exemplo, leitores de As Vinhas da Ira, de Steinbeck, têm mais chance de se sensibilizarem em relação à luta do trabalhador e de se tornarem mais céticos em relação às intenções das grandes corporações.

O fenômeno do transporte é evidenciado em estudos psicológicos com participantes que relatam a experiência de se envolver intensamente com uma história e de ter sua opinião alterada ao final da experiência. Em um desses estudos, estudantes de idade universitária foram expostos a uma história que promovia tolerância em relação à homossexualidade ${ }^{9}$. Na história, dois amigos de idade escolar conversam sobre sexualidade. Um deles recentemente se revelou homossexual; e o outro, que é heterossexual, reage de maneira positiva. Para controlar diferenças relativas à afinidade de cada participante pela ficção, os pesquisadores propuseram-lhes, logo no início do experimento, algumas perguntas para aferir se tinham propensão natural a se comover com histórias. De fato, os participantes que se declararam persuadidos pela história sobre homossexualidade foram também aqueles que, a princípio, apresentaram-se aos pesquisadores como altamente suscetíveis à ficção. Os participantes que foram persuadidos pela história são os mesmos que indicaram ter facilidade para se envolver com a trama de filmes, livros e outros tipos de discurso narrativo. São pessoas que já se reconheciam como tendo propensão para se identificar com os personagens e se comover com o seu sofrimento. Por outro lado, outros participantes, aqueles que logo declararam ter dificuldade para mergulhar na ficção, responderam à história de forma diferente. Ao final do experimento, eles se disseram menos afetados pelo contato com a história proposta pelos pesquisadores. Eles experimentaram o que pode ser chamado de "resistência imaginativa".

9 Sobre este e outros estudos, ver Mazzocco e Green (2011). 
Em síntese, os estudos sobre transporte corroboram apenas parcialmente o ponto de vista de West e Nussbaum. Por um lado, indicam que a literatura tem capacidade de transformar a opinião do leitor ${ }^{10}$. Por outro lado, a eficácia do transporte depende das tendências prévias do leitor. Há leitores que se envolvem mais facilmente com histórias e que são, portanto, mais suscetíveis ao transporte. Outros leitores são menos suscetíveis. Esses últimos dificilmente terão seu ponto de vista transformado por romances e outras obras de ficção. Eles experimentarão com mais frequência a resistência imaginativa. Isto é, eles terão dificuldade para mergulhar na história e realizar o exercício mental que a ficção exige: os personagens não parecerão interessantes, a história não parecerá natural ou verossímil.

O poder reformador da literatura também é objeto de discussão no plano histórico-sociológico. Pois, se a literatura fosse realmente capaz de desconstruir preconceitos e estereótipos entre seus leitores, ela também seria eventualmente capaz de abalar instituições políticas. Para isso, bastaria que livros com potencial reformador se disseminassem e alcançassem leitores politicamente influentes. Na literatura global, há diversos autores que recebem crédito por terem impulsionado transformações sociais de primeira importância. Considere alguns exemplosi1.

A cabana de Pai Tomás (1852), de Harriet Beecher Stowe, oferece um retrato crítico e dramático da escravidão nos Estados Unidos. O romance teria ajudado a provocar a Guerra Civil Americana e, indiretamente, a abolição da escravidão naquele país. Memórias de um caçador (1852), de Ivan Turguêniev, reúne contos que retratam o pobre camponês russo de forma humana, em contraste com o frívolo e cruel proprietário de terras. As histórias teriam ajudado a convencer o Tzar Alexandre II a abolir o sistema de servidão em 1861. Um dia da vida de Ivan Denissovitch (1962), de Alexandr Soljenitsin, é um relato detalhado das duras condições de vida em um campo de trabalho soviético. O livro teria contribuído para a difamação do stalinismo e, indiretamente, para a derrocada do sistema soviético.

10 É importante notar que uma transformação da opinião do leitor não gera necessariamente uma transformação comportamental, como vimos no item 3.2. Pessoas suscetíveis ao transporte ficam facilmente comovidas com histórias dramáticas; mas é possível que isso não resulte em mudança comportamental clara.

11 Estes e outros casos são estudados em detalhe por Michael Hanne (1994). 
Afirmações como essas devem ser interpretadas com cautela. Não é que sejam falsas, mas são todas um pouco enganosas. É muito natural entendê-las como apontando relações diretas entre a publicação de cada obra e a ocorrência da respectiva transformação social. Michael Hanne oferece algumas ressalvas em relação a esse tipo de interpretação. São ressalvas que nos ajudam a entender o tipo de contribuição - limitada e imprevisível - que a publicação de uma obra literária pode trazer para o progresso social.

Hanne começa com uma analogia. As afirmações destacadas acima podem dar a impressão de que uma obra literária é capaz de ter sobre as instituições sociais existentes efeito análogo ao de uma pedra lançada sobre águas calmas. Ao cair, a pedra geraria pequenas ondas que se espalhariam gradualmente sobre a superfície da água. A imagem é familiar, mas duvidosa. Uma analogia preferível seria a da pedra lançada sobre águas turbulentas. As ondas geradas pela pedra se chocam com ondas préexistentes que correm em diferentes sentidos e com elas interagem de maneira pouco previsível. A verdade é que todas as obras em destaque surgiram em contextos políticos complexos. Seu impacto social, por mais positivo que tenha sido, dependeu da sua interação com fatores sociais sobre os quais os autores não tinham controle. Em alguns casos, os efeitos da obra talvez não tenham sido aqueles que o autor almejava. Por pouco, algumas dessas obras poderiam até ter gerado mais efeitos negativos que positivos.

Hanne conta, por exemplo, alguns fatos sobre a biografia de Turguêniev que tornam duvidosa a ideia de que seu livro foi escrito com a intenção de promover a liberdade dos servos. O livro Memórias de um caçador introduz o leitor à crueldade do sistema de servidão e sugere que Turguêniev via com maus olhos a instituição. Mas quando o próprio Turguêniev herdou os empregados da família, em 1850, ele libertou apenas os servos domésticos, mantendo os servos do campo (embora permitisse que comprassem a sua liberdade se tivessem dinheiro para isso). Além disso, "Os limites ao senso de responsabilidade de Turguêniev [...] são indicados pela exploração sexual de servas, com quem ele teve uma criança, talvez duas" (Hanne, 1994, p. 46). Talvez Turguêniev quisesse promover o tratamento um pouco mais humano dos servos russos por seus 
proprietários. O efeito que se imputa às Memórias de um caçador, no entanto, é a própria abolição da servidão.

Mas, mesmo quando as intenções do autor são claras e benevolentes, o impacto social da sua obra é pouco previsível. Se, por um lado, a obra serve como fonte de inspiração para aqueles que concordam com sua mensagem, ela também pode alimentar a ira daqueles que a rejeitam. Não há sequer garantia de que a obra será lida pelos seus opositores, que tenderão a confiar no testemunho de terceiros e em eventuais distorções caluniosas. Segundo Hanne, A cabana de Pai Tomás estimulou tanto a simpatia dos americanos do norte quanto a fúria dos americanos do sul. O livro chegou a ser caracterizado pelos seus detratores, sem nenhum fundamento, como um livro que continha "ideias de depravação repugnante e prostituição habitual” (Hanne, 1994, p. 93). Décadas depois da publicação de A cabana do Pai Tomás, a impressão que se tinha do livro era amplamente baseada em representações teatrais grotescas que apagavam "toda a seriedade moral e sutil ambivalência de Stowe" (Hanne, 1994, p. 108).

Para além das interpretações equivocadas, livros que tocam assuntos socialmente sensíveis podem ser alvo de propaganda política e manipulação deliberada. Desde a sua publicação, Um dia na vida de Ivan Denissovitch foi usado como arma político-partidária. A princípio, o destino do livro era incerto em face da censura praticada na União Soviética. No entanto, em 1962, Nikita Krushchev promoveu pessoalmente a publicação da obra de Soljenitsin por crer que ela teria papel importante a cumprir na sua campanha política contra o stalinismo. O sucesso da campanha de Krushchev dependia da sua capacidade de trazer à tona os crimes de Stalin. Um relato vívido da vida nos campos de trabalho forçado poderia ser útil para esse propósito, ainda que o relato aparecesse na forma de um livro de ficção. Para Krushchev, pouco importava se a intenção real de Soljenitsin era realmente atacar o stalinismo ou se ele tinha alvos muito mais amplos, como o próprio socialismo soviético ou o totalitarismo de maneira geral.

Como vimos na seção 3.1, Lynn Hunt atribui aos romances epistolares do século XVIII o grande feito de terem preparado o caminho para a disseminação do conceito de direitos humanos. Ela não afirma que romances foram os únicos responsáveis por essa revolução política, mas diz 
que eles tiveram um papel importante a cumprir: "não me atrevo a dizer que a leitura de romances tenha sido [o único fator]. Ainda assim, ler romances parece especialmente pertinente, em parte porque o auge de determinando tipo de romance - o epistolar - coincide com o nascimento dos direitos humanos" (Hunt, 2009, p. 40). Noutro momento, ela lança a seguinte pergunta retórica: "Seria coincidência que os três maiores romances de identificação psicológica do século XVIII - Pamela (1740) e Clarissa (1747-8), de Richardson, e Júlia (1761), de Rousseau - teriam sido todos publicados no período que imediatamente precedeu o surgimento do conceito dos «direitos do homem»?" (Hunt, 2009, p. 39).

Hunt reconhece que os romances a que ela atribui o efeito positivo de expandir os limites da empatia dos leitores também foram objeto da acusação de que teriam efeitos socialmente degradantes: "Em 1792, um crítico inglês anônimo ainda insistia que «o aumento de romances ajuda a explicar o aumento da prostituição e os inúmeros adultérios e fugas de que ouvimos falar nas diferentes regiões do reino»" (Hunt, 2009, p. 53). É provável que o crítico inglês estivesse exagerando o aumento da prostituição e da infidelidade durante o auge do romance epistolar. Mas mesmo que ele pudesse apresentar evidências estatísticas, o que é que seu argumento provaria? A coincidência temporal entre a popularidade de romances que lidam com temas como o adultério e o aumento da infidelidade mostraria que os romances estão entre as causas da infidelidade? É possível que não haja nenhuma relação causal entre essas coisas ou até que a relação corra no sentido inverso: a percepção social de que o adultério ocorre com frequência pode servir como estímulo para que autores escrevam sobre o assunto.

Hunt não considera o fato de que sua posição está sujeita às mesmas objeções que podem ser opostas ao crítico inglês citado por ela. A coincidência temporal é indício relativamente fraco da existência de relação causal entre a popularidade do romance epistolar e o advento dos direitos humanos. É provável, aliás, que os fenômenos sejam ambos efeitos de alguma causa independente, como o capitalismo e a expansão da classe média. Esses e outros fatores sociais podem ter simultaneamente impulsionado o gosto pela literatura e a disseminação da antipatia burguesa por sistemas de castas. 
Há uma relação de coincidência temporal entre a publicação de cada um dos livros discutidos acima - A cabana de Pai Tomás etc. - e cada acontecimento político que já foi associado a eles - a abolição da escravidão etc. A pesquisa de Hanne se justifica precisamente como uma tentativa de investigar diversos fatores que poderiam ter contribuído para aqueles acontecimentos políticos e que, portanto, permitem-nos estimar com mais precisão a efetiva contribuição de cada obra. Hunt não oferece o mesmo tipo de análise minuciosa - o que faz sua conclusão parecer precipitada.

\subsection{Interpretação fraca}

Talvez seja exagero atribuir à literatura a capacidade de nos tornar pessoas melhores. No plano psicológico, vimos que há limitações ao poder persuasivo da literatura: por melhor que seja uma obra, nem todo leitor será "transportado" por ela. No plano histórico-sociológico, vimos que o impacto social de uma obra depende não só dos seus méritos morais, mas de uma série de contingências históricas sobre as quais o autor não tem controle. Mas isso não significa, é claro, que obras literárias sejam inócuas. Mesmo quando são incapazes de converter para o bem os seus leitores ou promover progresso social, boas obras ainda são capazes de nos motivar a pensar com cuidado sobre problemas morais importantes.

Os estudos de psicologia mencionados anteriormente também servem para esclarecer quais são os fatores que maximizam o poder persuasivo da ficção. Um mau contador de histórias pode ser pouco persuasivo mesmo quando tem um público suscetível ao transporte. O contador da história é sempre parcialmente responsável pelo sucesso da persuasão narrativa. Histórias persuasivas tendem a ser aquelas que apresentam as seguintes características (entre outras): descrição vívida de personagens, estrutura causal clara e - mais importante para os propósitos deste artigo - sutileza da mensagem (Mazzocco e Green, 2011, p. 27-30).

Para facilitar o transporte, é preciso descrever bem os personagens e o ambiente que os envolve. Quando leitores e ouvintes conseguem imaginar claramente o cenário e os indivíduos que nele agem, eles têm mais facilidade para mergulhar na história e para entender os sentimentos e motivações dos personagens. A estrutura da história, por sua vez, é importante porque espectadores costumam se sentir mais à vontade com 
histórias que têm início, meio e fim, nas quais os eventos são bem concatenados e é possível dizer claramente o que é causa de que efeito. Fios soltos e coincidências improváveis são problemas estruturais que prejudicam a persuasão narrativa ${ }^{12}$. Finalmente, as pessoas nem sempre reagem bem a recados óbvios ou tentativas descaradas de persuadir. Quando um vendedor ou um político conta uma experiência pessoal que pretende seja comovente, nós tendemos a reagir com ceticismo porque são mais óbvias as suas intenções. Antes de tudo, eles querem firmar um contrato ou conquistar um voto, o que faz com que as suas histórias possam parecer insinceras ${ }^{13}$. O mesmo princípio vale no campo da literatura. Um traço da ficção que é capaz de persuadir o leitor é sua relativa sutileza. Ela não dá seu recado de forma direta ou panfletária, mas de forma gradual e oblíqua.

Reconhecer a importância da sutileza da literatura é um passo importante para explicar a versão fraca da ideia de que a literatura é fonte de lições éticas. Uma característica de boas obras literárias é a sua sutileza $^{14}$. Elas não costumam apresentar uma mensagem óbvia, nem separam claramente os heróis dos vilões. Boas obras literárias não costumam pintar a vida social de preto e branco, mas pintam problemas morais com diversas luzes e com atenção aos seus vários aspectos. Não dão uma resposta pronta ao leitor, isto é, mesmo quando sugerem uma resposta ao final, atingem-na gradualmente, retratando os diferentes lados da questão. A boa literatura é avessa a respostas prontas. Como diz James Seaton, é importante valer-se da literatura para abordar problemas morais "não porque é possível esperar qualquer resposta unívoca [da literatura], mas porque a literatura oferece um controle salutar contra a disposição

12 Os autores dos estudos psicológicos em questão têm pouco a dizer sobre a possibilidade de que inversões de cronologia, incoerências e outros "problemas" estruturais sejam usados deliberadamente por autores cujo objetivo é chocar ou perturbar o leitor. Talvez essa omissão se deva ao fato de que os pesquisadores testam o poder persuasivo de narrativas despretensiosas que possam ter apelo para o leitor comum. O foco dos estudos não está no contato de leitores com obras narrativamente complexas ou inovadoras do ponto de vista literário.

13 A eficácia do discurso comercial e político depende, naturalmente, da habilidade do orador e do grau de ingenuidade do auditório. Há muitos políticos que conseguem envolver seu auditório com histórias pessoais. A questão é que o político e o vendedor enfrentam um desafio maior para superar o ceticismo do seu auditório do que oradores que não são vistos desde o princípio do discurso como se tivessem "segundas intenções".

14 Além de um fator que maximiza o poder persuasivo da narrativa, a sutileza costuma ser valorizada como algo que confere valor artístico à obra literária. 
humana para satisfazer-se com slogans, sobretudo aqueles do seu próprio partido" (Seaton, 1999, p. 507).

Considere um exemplo. Emma Bovary, a famosa protagonista do livro de Gustave Flaubert, trai o marido, Charles Bovary, em diferentes ocasiões. Charles é um marido apaixonado e um pai carinhoso. Emma se relaciona com outros homens e endivida o marido com seus hábitos extravagantes. Assim descrito, o livro pode soar como uma denúncia da frivolidade de Emma. Mas a história é muito mais complexa do que isso. Emma foi criada no campo e educada em um convento. Ela aceita casar-se com Charles provavelmente porque ele foi o primeiro homem que lhe propôs casamento. Charles também a impressionava por ser médico e gozar de certo prestígio na sociedade provinciana em que viviam. Em pouco tempo, porém, Emma percebe a mediocridade de Charles. Ele é médico, mas é um médico de ambição e habilidades limitadas. Na verdade, Charles tem diversos defeitos: ele é conformista, convencional e insensível aos anseios da mulher. Emma, por outro lado, é romântica, gosta de ler e sonha em viajar.

O leitor (a menos que seja insuscetível ao transporte) é induzido a sentir o profundo tédio e sufocamento moral que Emma sofre no papel de mãe, dona de casa e esposa de um médico de interior. Não era o que ela queria para sua vida. Emma se envolve com outros homens, decepciona-se também com eles, desespera-se e morre de forma trágica. A mensagem do livro não é clara em termos de heróis e vilões. O leitor fica divido entre o desprezo por Emma (que arruína psicológica e financeiramente um marido bondoso) e a compaixão pela prisão psicológica em que ela se encontra (em virtude do casamento sem paixão e da insipidez da vida no interior). Seja qual for a conclusão do leitor de Madame Bovary (1856), o livro o obriga a pensar com cuidado sobre o matrimônio e as convenções que o definem. A transformação não se dá necessariamente porque o leitor será convertido a alguma posição moral defendida claramente no livro pelo próprio Flaubert. Por outro lado, uma transformação mais sutil poderá se dar na medida em que o livro contribui para tornar o leitor uma pessoa com opiniões mais refletidas, profundas e ponderadas sobre o casamento. Em minha opinião, esse é o grande valor moral da literatura: bons livros, no mínimo, inspiram ponderação. 
Madame Bovary não é um romance que discute o direito explicitamente. As suas lições dizem respeito a outros aspectos da vida social: família, casamento, romantismo etc. Na seção 2, por outro lado, eu mencionei diferentes exemplos de obras literárias que têm o direito como tema proeminente. O valor das obras de Shakespeare, Swift, Glaspell, Kafka, Camus e Harper Lee não está na sua (duvidosa) capacidade de nos tornar juristas mais benevolentes, mas na sua capacidade de nos fazer pensar profunda e criticamente sobre o direito e de perceber problemas que costumam passar despercebidos.

\section{CONCLUSÃO}

O movimento "direito e literatura" - sobretudo na vertente que costuma ser identificada como "direito na literatura" - discute o valor da literatura para o jurista. Ler boas obras literárias seria uma forma de adquirir cultura geral, ganhar eloquência e também aprender lições importantes sobre direito e ética. Nem toda obra literária trata do direito, mas aquelas que exploram temas jurídicos são capazes de nos fazer refletir com cuidado sobre características gerais do sistema jurídico. Essas obras também são capazes de nos fazer refletir com cuidado sobre nossas obrigações éticas enquanto advogados, juízes, promotores, professores de direito etc.

Este artigo procurou mostrar que a capacidade da literatura para nos fazer refletir sobre as obrigações éticas do jurista não deve ser confundida com a sua (suposta) capacidade de nos humanizar, isto é, de fazer de nós advogados mais honestos, promotores mais compreensivos, juízes mais justos. O papel da literatura como agente desse tipo de reforma moral está sujeito a diferentes objeções. É uma hipótese empírica que ainda não recebeu clara confirmação nos campos da psicologia e da sociologia. Também é uma ideia politicamente arriscada, que serve aos propósitos de censores e outros inimigos da literatura.

Outra maneira de caracterizar a posição defendida neste artigo é como uma espécie de meio-termo entre posições extremas que já foram defendidas por outros autores. Se, por um lado, há quem pense que a literatura é capaz de fazer de nós pessoas melhores, por outro lado há quem pense que a literatura estimula a "anarquia moral" (Posner, 2009, p. 463). 
É verdade que há obras que transmitem uma mensagem moral de inclusão e benevolência, mas outras transmitem uma mensagem de intolerância e preconceito. Ao falar em anarquia moral, Posner sugere que o jurista que entre em contato com os dois tipos de obra terá acesso a mensagens diametralmente opostas - positivas e negativas - e, portanto, só saberá derivar da experiência alguma espécie de niilismo ou relativismo moral.

É aqui que fica evidente a importância dos professores de "direito e literatura” (como foi sugerido na seção 3.2). É verdade que a leitura indiscriminada de obras literárias pode expor o leitor a mensagens antagônicas. Mas o ensino de "direito e literatura" exige discriminação não entre obras "boas" e "más", mas entre obras panfletárias e obras sutis. As obras que costumam ser valorizadas em cursos de "direito e literatura" são obras do segundo tipo; são aquelas que não oferecem respostas óbvias e definitivas para os problemas que suscitam ou que as oferecem apenas de forma nuançada. A lição dessas obras não é o relativismo - isto é, a ideia de que "vale tudo" no campo da moral -, mas a ideia muito diferente de que problemas morais exigem ponderação e reflexão cuidadosa.

É preciso reconhecer que também depende de corroboração empírica a versão fraca da ideia de que a literatura é fonte de lições éticas, isto é, a hipótese de que a boa literatura pode nos motivar a refletir cuidadosamente sobre questões morais complexas. Mas, mesmo na falta de experimentos específicos que testem essa hipótese, ela tem em relação à versão forte vantagens claras. A versão fraca evita as demais objeções discutidas ao longo do artigo. A versão fraca vale tanto para obras benevolentes quanto para obras com mensagens moralmente duvidosas: qualquer obra pode provocar reflexão, seja qual for sua mensagem final, desde que a veicule de forma sutil. Além disso, a versão fraca não está igualmente sujeita aos abusos dos censores. Censores costumam invocar a ideia de que a literatura é capaz de corromper, não a ideia de que ela nos faz pensar. Regimes políticos fechados também se preocupam com o segundo efeito, mas essa preocupação dificilmente aparece em sua retórica oficial.

\section{REFERÊNCIAS}

FLAUBERT, Gustave. Madame Bovary. Trad. de Fúlvia Moretto. São Paulo: Nova Alexandria, 2009. 
HANNE, Michael. The Power of the Story: Fiction and Political Change. Providence: Berghahn Books, 1994. 262p.

HUNT, Lynn. A invenção dos direitos humanos: uma história. Trad. de Rosaura Eichenberg. São Paulo: Companhia das Letras, 2009. 285p.

KEEN, Suzanne. Empathy and the novel. New York: Oxford University Press, 2007. 242p.

KISSAM, Philip. Disturbing images: literature in a jurisprudence course. Legal Studies Forum, v. 22, p. 329-351, 1998.

LADENSON, Elisabeth. Dirt for art's sake: books on trial from «Madame Bovary» to «Lolita». Ithaca: Cornell University Press, 2007. 272p.

LANDY, Joshua. A nation of Madame Bovarys: on the possibility and desirability of moral improvement through fiction. In: HAGBERG, Garry (Org.). Art and ethical criticism. Malden: Blackwell Publishing, 2008. p. 63-94.

LIAO, Shen-yi; GENDLER, Tamar. Pretense and imagination. Wiley Interdisciplinary Reviews: Cognitive Science, v. 11, p. 79-94, 2010.

MAZZOCCO, Philip; MELANIE, Green. Narrative persuasion in legal settings: what's the story? The Jury Expert, v. 23, n. 3, p. 27-34, 2011.

NUSSBAUM, Martha. Poetic justice: the literary imagination and public life. Boston: Beacon Press, 1995. 143p.

POSNER, Richard. Law and literature. 3. ed. Cambridge: Harvard University Press, 2009, 592p.

SEATON, James. Law and literature: works, criticism and theory. Yale Journal of Law \& the Humanities, v. 11, n. 2, p. 479-507, 1999.

TURGUÊNIEV, Ivan. Memórias de um caçador. Trad. de Irineu Perpetuo. 2. ed. São Paulo: Editora 34, 2017. 488p.

WEST, Robin. Economic man and literary woman: one contrast. Mercer Law Review, v. 39, p. 867-878, 1988.

Idioma original: Português

Recebido: 12/04/18

Aceito: 28/11/18 